\title{
Timing of Completion of the First Meiotic Division in Bovine Oocytes after Maintenance of Meiotic Arrest with Cycloheximide and Their Subsequent Development
}

\author{
Kazuhiro SAEKI1)*, Yoshikazu NAGAO**, Masao KISHI, Masaki NAGAI and Akira IRITANI ${ }^{1)}$ \\ Embryo Transplantation Laboratory , Snow Brand Milk Products Co., Ltd., Tomakomai, Hokkaido 059-13 and ${ }^{1 / R e s e a r c h ~ I n s t i t u t e ~ f o r ~}$ \\ Biology-Oriented Science and Technology, Kinki University, Wakayama 649-64, Japan
}

(Received 12 August 1997/Accepted 9 November 1997)

ABSTRACT. This study examined the timing of completion of meiosis I of bovine oocytes in which meiotic resumption had been inhibited by cycloheximide (CHX), and also determined the optimum interval of maturation in culture for subsequent fertilization and development. Most oocytes treated with CHX reached metaphase II at $16 \mathrm{hr}$ in the maturation culture, while control oocytes did at $20 \mathrm{hr}$. CHX-treated oocytes cultured for $16 \mathrm{hr}$ were normally fertilized but failed to develop into blastocysts. Maturation in culture for $20 \mathrm{hr}$ resulted in comparable development for control oocytes. The results indicate that nuclear maturation of CHX-treated oocytes was completed $4 \mathrm{hr}$ faster than for control oocytes, however the same interval of maturation as that of control oocytes is necessary for subsequent development to blastocysts. - KEY WORDS: cycloheximide, inhibition of bovine meiotic resumption, maturation.

J. Vet. Med. Sci. 60(4): 523-526, 1998

Mammalian extrafollicular oocytes resume meiosis spontaneously [15]. Active protein synthesis is required for the resumption in oocytes of pigs, sheep, goats and cattle $[5,6,8,9]$. Bovine oocytes do not undergo germinal vesicle breakdown (GVBD) in media with protein synthesis inhibitors such as cycloheximide (CHX) [6, 19, 21] and puromycin [10]. The inhibition of GVBD is fully reversible, since after washing the inhibitors, oocytes undergo GVBD $[6,10,21]$. Moreover, oocytes maintained in meiotic arrest by CHX can mature in vitro [21] and develop to blastocysts following in vitro fertilization [17]. It has been reported that normal fertilizability and developmental capacity are kept only within several hours after nuclear maturation of bovine in vitro matured oocytes [2]. However, the remarkable fact with oocytes after reversal of meiotic arrest with protein synthesis inhibitors is that the time sequence of GVBD is twice as fast as the control oocytes [7, 8, 10, 21]. The timing of completion of the first meiotic division (meiosis I) in oocytes treated with $\mathrm{CHX}$ and subsequent fertilizability and developmental capacity of oocytes have not yet been reported.

Here, examinations were made to determine the time sequence of nuclear maturation of bovine oocytes which had been maintained in meiotic arrest with CHX for $24 \mathrm{hr}$ and to determine the optimum interval of maturation in culture of oocytes for subsequent fertilization and development to the blastocyst stage.

Bovine cumulus-oocyte-complexes (COCs) were collected from the small antral follicles (2 to $5 \mathrm{~mm}$ in diameter) of slaughterhouse ovaries transported and stored in saline $(0.9 \% \mathrm{w} / \mathrm{v} \mathrm{NaCl})$ for $7-9 \mathrm{hr}$ at $18-22^{\circ} \mathrm{C}$. COCs were washed in $25 \mathrm{mM}$ HEPES-buffered TCM-199 with

* Correspondence to: Dr. SAeKi, K., Research Institute for Biology-Oriented Science and Technology, Kinki University, Wakayama 649-64, Japan.

** Present AdDress: University Farm, Department of Animal Science, Faculty of Agriculture, Utsunomiya University, Mohka, Tochigi 321-44, Japan.
Earle's salts (Cat. No. 12340, Gibco Laboratories, Grand Island, NY, U.S.A.), supplemented with $0.1 \%(\mathrm{w} / \mathrm{v})$ polyvinyl alcohol (PVA; M.W. 40,000, Sigma Chemical, St Louis, MO), $0.5 \mathrm{mM}$ Na-pyruvate (Nacalai Tesque, Kyoto, Japan) and 1\% (v/v) antibiotic antimycotic solution (Gibco, m-TCM199) three times. Maintenance of meiotic arrest was carried out as described by Saeki et al. [17]. Ten COCs were incubated in $50 \mu l$ drops of m-TCM199 supplemented with $10 \%$ (v/v) fetal calf serum (Gibco, mTCM-199+FCS) and $10 \mu \mathrm{g} / \mathrm{ml}$ cycloheximide (CHX, Sigma), $0.02 \mathrm{AU} / \mathrm{m} l$ FSH (Antoine, Denka Seiyaku, Tokyo, Japan) and $1 \mu \mathrm{g} / \mathrm{m} l$ estradiol- $17 \beta\left(\mathrm{E}_{2}\right.$, Sigma $)$ in a plastic dish (Falcon 1007, Becton and Dickinson Labware, Lincoln Park, NJ, U.S.A.) covered with mineral oil (Squibb, Princeton, NJ, U.S.A.) for $24 \mathrm{hr}$ at $39^{\circ} \mathrm{C}$ in $5 \% \mathrm{CO}_{2}$ in air at high humidity. Following incubation, some oocytes were fixed in acetic alcohol (1:3) and stained with aceto-orcein for examination of the nuclear stage [18].

The COCs were washed five times thoroughly and cultured in m-TCM199 supplemented with $0.02 \mathrm{AU} / \mathrm{m} l \mathrm{FSH}$ and $1 \mu \mathrm{g} / \mathrm{m} l \mathrm{E}_{2}$ (maturation medium) [16] in a plastic dish covered with mineral oil (10 COCs/50 $\mu$ l droplet) for 12-24 hr at $39^{\circ} \mathrm{C}$ in $5 \% \mathrm{CO}_{2}$ in air at high humidity.

In vitro fertilization was carried out as described by Nagao et al. [11]. Briefly, COCs cultured for 16, 20 and 24 $\mathrm{hr}$ in the maturation medium were inseminated with Percollwashed spermatozoa [16] $\left(1 \times 10^{6} \mathrm{cells} / \mathrm{m} l\right)$ in defined medium [1] modified by excluding glucose and supplemented with $1 \mu \mathrm{g} / \mathrm{m} l$ heparin [14] $(10 \mathrm{COCs} / 100 \mu l$ droplet). Oocytes and spermatozoa were co-incubated for 6 hr at $39^{\circ} \mathrm{C}$ in $5 \% \mathrm{CO}_{2}$ in air with high humidity. Following co-incubation, the oocytes were freed from the spermatozoa and cumulus cells and cultured in modified synthetic oviduct fluid medium (m-SOFM) [20] supplemented with $3 \mathrm{mg} / \mathrm{m} l$ bovine serum albumin (A-4378, Sigma) for 7 days (168 hr) at $39^{\circ} \mathrm{C}$ in $5 \% \mathrm{CO}_{2}, 5 \% \mathrm{O}_{2}$ and $90 \% \mathrm{~N}_{2}$ with high humidity (20-30 embryos/50 $\mu$ l droplet) [12]. Some embryos were fixed and stained $18 \mathrm{hr}$ after insemination for assessment of fertilization [16]. Total fertilization included all penetrated 


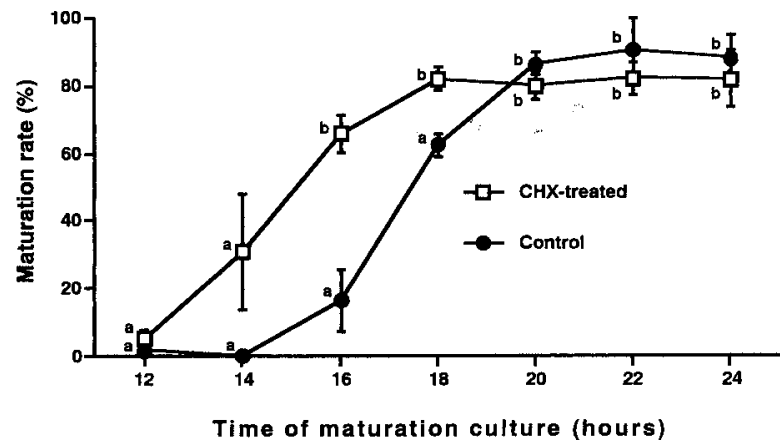

Fig. 1. Time sequence of nuclear maturation of bovine oocytes after reversal of meiotic arrest by CHX. CHX-treated oocytes were incubated in a medium containing $10 \mu \mathrm{g} / \mathrm{m} l \mathrm{CHX}$ for 24 $\mathrm{hr}$, then washed and cultured in maturation medium. Control oocytes were collected from ovaries $24 \mathrm{hr}$ after the treated group and matured without inhibition. Points are the mean and bars indicate SEM of three replicates. Means with different letters are significantly different $(\mathrm{P}<0.05)$ in the same treatments. The total number of oocytes within each treatment ranged from 52 to 58 .

oocytes; normal fertilization represented only those oocytes with two pronuclei and one sperm tail. Polyspermic fertilization was also recorded as oocytes with more than two male pronuclei and/or decondensed sperm heads with their associated tails. The remaining embryos were examined with a stereomicroscope $(\times 60)$ for cleavage and blastocyst development 7 days after insemination.

Each experiment was repeated three times. Percentage data obtained from each experiment were analyzed by analysis of variance (ANOVA) followed by Fisher's protected least significant difference (PLSD) test with Stat View software (Abacus Concepts, Stat View, version J-4.11, Abacus Concepts Inc., Berkeley CA, U.S.A.). The data were expressed as mean \pm SEM.

In the first experiment, the time course of nuclear maturation of bovine oocytes treated with $\mathrm{CHX}$ for $24 \mathrm{hr}$ was examined. CHX-treated oocytes were cultured for 12 , $14,16,18,20,22$ and $24 \mathrm{hr}$ in the maturation medium. Oocytes were fixed and stained at each end point for assessment of nuclear maturation. Oocytes collected from ovaries on the day that treated oocytes were moved to the maturation medium served as a control. The percentage of oocytes arrested at the germinal vesicle stage after $24 \mathrm{hr}$ culture in medium with $\mathrm{CHX}$ was $98 \pm 4 \%$. CHX effectively inhibited meiotic resumption in bovine oocytes. As shown in Fig. 1, at $12 \mathrm{hr}$ following onset of maturation culture, very few oocytes in both groups completed nuclear maturation (2-5\%). Maturation rates gradually increased as the culture interval increased, and reached a maximum rate at $16 \mathrm{hr}$ in the CHX-treated group $(66 \pm 6 \%)$ and at $20 \mathrm{hr}$ in the control group $(86 \pm 4 \%)$. The results indicate that the interval for nuclear maturation of bovine oocytes which were maintained in meiotic arrest with $\mathrm{CHX}$ is $4 \mathrm{hr}$ shorter than that of oocytes just released from the follicles. The time sequence of GVBD in bovine, ovine, caprine and porcine oocytes after maintenance of meiotic arrest with protein synthesis inhibitors is two to three times as fast as in untreated oocytes [7-10,21]. The interval required for nuclear maturation of CHX-inhibited oocytes may thus be shortened by the acceleration of the GVBD sequence.

In the second experiment, fertilizability and developmental capacity of CHX-treated oocytes matured for different intervals were examined. COCs were cultured for 16,20 or $24 \mathrm{hr}$ in the maturation medium. They were then fertilized in vitro and cultured to the blastocyst stage. Oocytes collected from ovaries on the day that treated oocytes were moved to the maturation medium served as a control. High penetration rates were obtained in nearly all oocytes in all groups $(\mathrm{P}>0.05$, Table 1$)$. A higher rate of polyspermic fertilization was obtained with control oocytes, cultured for $16 \mathrm{hr}$ in the maturation medium, which had not completed meiosis I at insemination, than for the other groups $(\mathrm{P}<0.05)$. It was also noted by Niwa et al. [13] that bovine maturing oocytes could be fertilized in vitro but with high incidence of polyspermy. They suggested that there seemed to be no block to polyspermy in immature bovine oocytes [13]. On the other hand, CHX-treated oocytes were fertilized normally, even though they were cultured for only $16 \mathrm{hr}$ (Table 1). Therefore, CHX-treated bovine oocytes which have completed meiosis I may become capable of

Table 1. In vitro maturation, fertilization and development of CHX-treated oocytes for 16 and $20 \mathrm{hr}$ maturation culture after reversal ${ }^{\mathrm{a})}$

\begin{tabular}{|c|c|c|c|c|c|c|c|c|c|c|}
\hline \multirow{3}{*}{$\begin{array}{l}\text { Duration } \\
\text { of } \\
\text { Maturation } \\
\text { (h) }\end{array}$} & \multirow[b]{3}{*}{$\begin{array}{l}\text { Treat- } \\
\text { ment }\end{array}$} & \multicolumn{6}{|c|}{ Fertilization } & \multirow{2}{*}{\multicolumn{3}{|c|}{ Development }} \\
\hline & & \multicolumn{2}{|c|}{ Maturation } & \multirow[b]{2}{*}{$\begin{array}{l}\text { No. of } \\
\text { oocytes }\end{array}$} & \multicolumn{3}{|c|}{$\%^{\text {b) }}$ fertilized } & & & \\
\hline & & $\begin{array}{l}\text { No. of } \\
\text { oocytes }\end{array}$ & $\begin{array}{c}\%^{\mathrm{b})} \\
\text { matured }\end{array}$ & & Total & Normal & $\begin{array}{l}\text { Poly- } \\
\text { spermic }\end{array}$ & $\begin{array}{l}\text { No. of } \\
\text { embryos }\end{array}$ & $\begin{array}{c}\%^{\mathrm{b})} \\
\text { cleaved }\end{array}$ & $\begin{array}{c}\%^{\text {b) }} \text { of } \\
\text { blastocysts }\end{array}$ \\
\hline 16 & Control $^{\text {c) }}$ & 38 & $19 \pm 5^{\mathrm{e})}$ & 42 & $87 \pm 6$ & $29 \pm 5^{\mathrm{e})}$ & $54 \pm 14^{\mathrm{e})}$ & 121 & $70 \pm 6$ & $16 \pm 9^{e)}$ \\
\hline 16 & $\mathrm{CHX}^{\mathrm{d})}$ & 36 & $73 \pm 8^{f}$ & 35 & $86 \pm 8$ & $73 \pm 4^{f}$ & $13 \pm 4^{\mathrm{f}}$ & 109 & $65 \pm 1$ & $11 \pm 3^{\mathrm{e})}$ \\
\hline 20 & Control $^{\text {() }}$ & 39 & $88 \pm 5^{f)}$ & 40 & $90 \pm 6$ & $69 \pm 1^{\mathrm{f}}$ & $\left.21 \pm 7^{f}\right)$ & 117 & $79 \pm 4$ & $35 \pm 6^{f)}$ \\
\hline 20 & $\mathrm{CHX}^{\mathrm{d})}$ & 36 & $74 \pm 4^{f)}$ & 39 & $90 \pm 6$ & $64 \pm 7^{f)}$ & $26 \pm 2^{\mathrm{f})}$ & 119 & $73 \pm 1$ & $31 \pm 8^{f)}$ \\
\hline
\end{tabular}

a) Data from three replicates.

b) Percentages are expressed as mean \pm SEM.

c) Oocytes were collected from ovaries $24 \mathrm{hr}$ after $\mathrm{CHX}$ treatment and matured without inhibition.

d) Oocytes were treated with CHX for $24 \mathrm{hr}$, then washed and matured.

e), f) Values differ significantly in the same columns $(\mathrm{P}<0.05$, ANOVA followed by Fisher's PLSD test). 
Table 2. In vitro maturation, fertilization and development of CHX-treated oocytes for 20 and $24 \mathrm{hr}$ maturation culture after reversal ${ }^{\text {a) }}$

\begin{tabular}{|c|c|c|c|c|c|c|c|c|c|c|}
\hline \multirow{3}{*}{$\begin{array}{l}\text { Duration } \\
\text { of } \\
\text { maturation } \\
\text { (h) }\end{array}$} & \multirow[b]{3}{*}{$\begin{array}{l}\text { Treat- } \\
\text { ment }\end{array}$} & \multicolumn{6}{|c|}{ Fertilization } & \multirow{2}{*}{\multicolumn{3}{|c|}{ Development }} \\
\hline & & \multicolumn{2}{|c|}{ Maturation } & \multirow[b]{2}{*}{$\begin{array}{l}\text { No. of } \\
\text { oocytes }\end{array}$} & \multicolumn{3}{|c|}{$\%^{\text {b) }}$ fertilized } & & & \\
\hline & & $\begin{array}{l}\text { No. of } \\
\text { oocytes }\end{array}$ & $\begin{array}{c}\%^{\mathrm{b})} \\
\text { matured }\end{array}$ & & Total & Normal & $\begin{array}{l}\text { Poly- } \\
\text { spermic }\end{array}$ & $\begin{array}{l}\text { No. of } \\
\text { embryos }\end{array}$ & $\begin{array}{c}\% \mathrm{~b}) \\
\text { cleaved }\end{array}$ & $\begin{array}{c}\% \text { b) of } \\
\text { blastocysts }\end{array}$ \\
\hline 20 & Control ${ }^{\text {c) }}$ & 40 & $77 \pm 3$ & 55 & $83 \pm 5^{\mathrm{e})}$ & $57 \pm 9$ & $32 \pm 9$ & 130 & $83 \pm 2$ & $32 \pm 3$ \\
\hline 20 & $\mathrm{CHX}^{\mathrm{d})}$ & 45 & $82 \pm 2$ & 54 & $98 \pm 2^{\mathrm{f})}$ & $73 \pm 8$ & $22 \pm 10$ & 160 & $78 \pm 1$ & $24 \pm 9$ \\
\hline 24 & Control $^{\text {c) }}$ & 41 & $85 \pm 3$ & 55 & $\left.98 \pm 2^{f}\right)$ & $68 \pm 3$ & $31 \pm 3$ & 134 & $85 \pm 2$ & $33 \pm 10$ \\
\hline 24 & $\mathrm{CHX}^{\mathrm{d})}$ & 40 & $82 \pm 2$ & 57 & $83 \pm 4^{\mathrm{e})}$ & $68 \pm 2$ & $15 \pm 5$ & 154 & $77 \pm 5$ & $26 \pm 11$ \\
\hline
\end{tabular}

a) Data from three replicates.

b) Percentages are expressed as mean \pm SEM.

c) Oocytes were collected from ovaries $24 \mathrm{hr}$ after $\mathrm{CHX}$ treatment and matured without inhibition.

d) Oocytes were treated with CHX for $24 \mathrm{hr}$, then washed and matured.

e) ,f) Values differ significantly in the same columns ( $<<0.05$, ANOVA followed by Fisher's PLSD test).

blocking polyspermy even in a short culture interval. Most embryos were cleaved similarly in all groups $(\mathrm{P}>0.05)$. In control groups, maturing oocytes cultured for $16 \mathrm{hr}$ in the maturation medium, which were fertilized but with high incidence of polyspermy, consequently failed to develop into blastocysts $(\mathrm{P}<0.05)$. After reaching metaphase II, the control oocytes developed into blastocysts following in vitro fertilization. Although CHX-treated oocytes cultured for the shorter interval (16 hr) were successfully matured and fertilized, they failed to develop into blastocysts $(\mathrm{P}<0.05$, Table 1). A longer interval $(20 \mathrm{hr})$ in the maturation culture was necessary for the CHX-treated oocytes to obtain a similar rate of blastocyst development to that of the control oocytes. Since development of oocytes inseminated $4 \mathrm{hr}$ after completion of meiosis I ( $20 \mathrm{hr}$ ) following maintenance of meiotic arrest with $\mathrm{CHX}$ was superior to those inseminated immediately after nuclear maturation (16 hr), an experiment was carried out to determine if $4 \mathrm{hr}$-extended culture of control oocytes in maturation medium after nuclear maturation enhances subsequent development. Table 2 indicates that the development into blastocysts of control oocytes cultured for $24 \mathrm{hr}$ did not increase as compared to that for $20 \mathrm{hr}(\mathrm{P}>0.05)$. The present results confirm our previous observation [17] that CHX-treated oocytes were normally fertilized and developed to blastocysts, when they were cultured in maturation medium after reversal of meiotic arrest as long as control oocytes completed meiosis I (Tables 1 and 2). CHX-treated oocytes cultured for $16 \mathrm{hr}$ were successfully fertilized but failed to develop into blastocysts, although the majority reached metaphase II when inseminated. Development of CHXtreated oocytes comparable to that of control oocytes was observed when inseminated $4 \mathrm{hr}$ after nuclear maturation (20 hr, Table 1). Cytoplasmic maturation of mammalian oocytes originally described by Thibault et al. [22] involves the development of cytoplasmic signals essential for completing fertilization and directing early embryonic development. These signals appear to result from translation of maternal mRNA synthesized during oogenesis [3]. Eppig [4] recently hypothesized with mouse experiments that for embryogenesis, immature oocytes must be competent to complete the 2-cell stage to blastocyst transition, and the factor (s) for this transition are synthesized in oocytes during maturation. If the hypothesis is acceptable for bovine oocytes, the interval (16 hr) for completion of nuclear maturation of CHX-treated oocytes may not be long enough for the synthesis of such transition factor (s) in oocytes. It is possible that the synthesis in CHX-treated oocytes may take at least a similar interval $(20 \mathrm{hr})$ as that which allows control oocytes to complete nuclear maturation.

In conclusion, nuclear maturation of CHX-treated oocytes is accelerated and completed $4 \mathrm{hr}$ faster than control oocytes, however the same interval in the maturation culture as control oocytes is necessary to complete meiosis I for subsequent development to blastocysts.

ACKNOWLEDGMENT. We thank the Meat Inspection Office of Hayakita for providing the materials used in this study.

\section{REFERENCES}

1. Brackett, B.G. and Oliphant, G. 1975. Biol. Reprod. 12: 260274.

2. Chian, R. C., Nakahara, H., Niwa, K. and Funahashi, H. 1992. Theriogenology 37: 665-672.

3. Cascio, S. M. and Wassarman, P. M. 1982. Dev. Biol. 89: 397-408.

4. Eppig, J. J. 1993. pp. 43-53. In: Preimplantation Embryo Development (Bavister, B.D. ed.), Springer-Verlag New York, Inc. New York, NY.

5. Fulka, Jr. J., Motlík, J., Fulka, J. and Jílek, F. 1986. J. Reprod. Fertil. 77: 281-285.

6. Hunter, A. G. and Moor, R. M. 1987. J. Dairy Sci. 70: 16461651.

7. Kubelka, M., Motlík, J., Fulka, J., Jr., Procházka, R., Rimkevicová, Z. and Fulka, J. 1988. Gamete Res. 19: 423431.

8. Le Gal, F., Gall, L. and De Smedt, V. 1992. Mol. Reprod. Dev. 32: 1-8.

9. Moor, R. M. and Crosby, I. M. 1986. J. Embryol. Exp. Morphol. 94: 207-220. 
10. Motlík, J., Lie, B. and Shioya, Y. 1990. Biol. Reprod. 43: 994-998.

11. Nagao, Y., Saeki, K., Hoshi, M., Takahashi, Y. and Kanagawa, H. 1995. Theriogenology 44: 433-444.

12. Nagao, Y., Saeki, K., Hoshi, M. and Nagai, M. 1995. J. Reprod. Dev. 41: j29-j36 (in Japanese).

13. Niwa, K., Park, C. K. and Okuda, K. 1991. J. Reprod. Fertil. 91: 329-226.

14. Parrish, J. J., Susko-Parrish, J. L., Leibfried-Rutledge, M. L., Critser, E. S., Eyestone, W. H. and First, N. L. 1986. Theriogenology 25: 591-600.

15. Pincus, G. and Enzmann, E. V. 1935. J. Exp. Med. 62: 665675.

16. Saeki, K., Hoshi, M., Leibfried-Rutledge, M. L. and First, N.
L. 1990. Theriogenology 34: 1035-1039.

17. Saeki, K., Nagao, Y. and Nagai, M. 1997. Theriogenology 48: 1161-1172.

18. Sato, E., Iritani, A. and Nishikawa, Y. 1978. Jpn. J. Zootech. Sci. 49: 236-242 (in Japanese).

19. Sirard, M. A., Florman, H. M., Leibfried-Rutledge, M. L., Barnes F. L., Sims M. L. and First, N. L. 1989. Biol. Reprod. 40: $1257-1263$.

20. Takahashi, Y. and First, N. L. 1992. Theriogenology 37: $963-$ 978.

21. Tatemoto, H., Horiuchi, T. and Terada, T. 1994. Theriogenology 42: 1141-1148.

22. Thibault, C., Gerard, M. and Menezo, Y., 1975. Ann. Biol. Anim. Biochem. Biophys. 15: 705-714. 